\title{
Correction to: Phytochemicals and in vitro anti-apoptotic properties of ethanol and hot water extracts of Cassava (Manihot esculenta Crantz) peel biogas slurry following anaerobic degradation
}

\author{
Oluwaseyi Paul Olaniyan ${ }^{1 *}$ and Ebenezer Idowu O. Ajayi ${ }^{1,2}$
}

Correction to: Clin Phytosci 7, 77 (2021)

https://doi.org/10.1186/s40816-021-00311-2

Following the publication of the original article [1], the authors identified an error in the author names of Oluwaseyi Paul Olaniyan and Ebenezer Idowu O. Ajayi. The given name and family name were erroneously transposed.

The incorrect author names are: Olaniyan Oluwaseyi Paul and Ajayi Ebenezer O. Idowu.

The correct author names are: Oluwaseyi Paul Olaniyan and Ebenezer Idowu O. Ajayi.

Similarly, a slight correction has been made to the title:

Former title: Phytochemicals and in vitro antiapoptotic properties of ethanol and hot water extracts of Cassava peel of Cassava (Manihot Esculenta Crantz) biogas slurry following anaerobic degradation

New title: Phytochemicals and in vitro anti-apoptotic properties of ethanol and hot water extracts of Cassava (Manihot esculenta Crantz) peel biogas slurry following anaerobic degradation

The author group and article title have been updated above and the original article [1] has been corrected.

\section{Author details}

'Department of Biochemistry, Faculty of Basic and Applied Sciences, Osun State University, Osogbo, Nigeria. ${ }^{2}$ Biofisica Membrana y Nanotecnologia, Instituto Ferreyra, Av. Velez Sarsfield, 2434 Friuli, Cordoba, Argentina.

Published online: 15 November 2021

Reference

1. Olaniyan, Ajayi. Phytochemicals and in vitro anti-apoptotic properties of ethanol and hot water extracts of Cassava peel of Cassava (Manihot Esculenta Crantz) biogas slurry following anaerobic degradation. Clin Phytosci. 2021;7:77.

\footnotetext{
The original article can be found online at https://doi.org/10.1186/s40816021-00311-2.

* Correspondence: Olaniyanoluwaseyi74@gmail.com

'Department of Biochemistry, Faculty of Basic and Applied Sciences, Osun

State University, Osogbo, Nigeria
}

\section{Springer Open}

(c) The Author(s). 2021 Open Access This article is licensed under a Creative Commons Attribution 4.0 International License, which permits use, sharing, adaptation, distribution and reproduction in any medium or format, as long as you give appropriate credit to the original author(s) and the source, provide a link to the Creative Commons licence, and indicate if changes were made. The images or other third party material in this article are included in the article's Creative Commons licence, unless indicated otherwise in a credit line to the material. If material is not included in the article's Creative Commons licence and your intended use is not permitted by statutory regulation or exceeds the permitted use, you will need to obtain permission directly from the copyright holder. To view a copy of this licence, visit http://creativecommons.org/licenses/by/4.0/. 